\title{
Study on Green Transport City Evaluation Index System: Case Study of Qingdao City
}

\author{
Zhen-Hua Feng ${ }^{1,2}$, Bin Ouyang ${ }^{3}$, Jie Guo $^{3}$, Shuang Wang ${ }^{3}$, Hai-Ying Zhang ${ }^{3}$ \& \\ Shu-Xue Chen ${ }^{3}$ \\ ${ }^{1}$ China Academy of Transportation Sciences, Beijing 100029, China \\ ${ }^{2}$ School of Management and Economics, Beijing Institute of Technology, Beijing 100081, China \\ ${ }^{3}$ China Academy of Transportation Sciences, Beijing 100029, China
}

KEYWORD: transport; green transport city; evaluation index system; Qingdao.

ABSTRACT: Based on four categories of indexes such as intensity indexes etc., this paper combines with actual characteristics of Chinese city, discusses about and builds a green and low-carbon city evaluation index system, and puts forward a set of simple and practical evaluation methods and standards evaluation system; with case study of Qingdao City, this paper also conducts empirical evaluation of current development level in 2013 and planning level in 2020 respectively, and verifies scientific validity of the index system.

\section{INTRODUCTION}

Transportation is basic cause, leading industry and service industry of national economy and social development, and is also one of industries with intensive resources and great influence on the environment [1]. Thus, the Ministry of Transport of the People's Republic of China explicitly proposes to accelerate the transformation of transportation development mode and build a green and low-carbon transportation system [2]. The development of green and low-carbon city has become an important window for countries in the world to develop green and low-carbon economy, important content of building a green and low-carbon transportation system and important direction of promoting sustainable development of cities [3]. At the end of 2012, China's total transport energy consumption and carbon emissions were 454 million tce and 926 million CO2, accounting for 12.67 percent and 12.19 percent of total energy consumption and carbon emissions respectively [4]. It is of important strategic and practical significance to realize green and low-carbon development with rapid expansion of city scale and significant improvement of service capacity, which has become a severe challenge for the modernization of Chinese cities.

For the development of green and low-carbon cities, scientific evaluation and policy guidance are critical and essential. Currently, domestic and foreign scholars have done a lot of researches on lowcarbon evaluation system [5, 6], and evaluation methods mainly include input-output, analytic hierarchy process (AHP), fuzzy comprehensive evaluation, data envelopment analysis (DEA), and principal component analysis (PCA) etc. [7-9]. For example, OECD (2008) builds core environmental indexes to measure the influence on environmental development by environmental pressure index and direct and indirect indexes of environmental conditions etc.[10]. Dagoumas and Barker (2010) analyzes carbon emission of UK by E3MG (Energy Economy Environment Model), and puts forward some suggestions about its decarburization paths [11]. Shimada et al (2007) constructed a method to analyze the long-term development scene of regional low-carbon economy [12]. Fu et al, (2010) constructed a low-carbon economic development level evaluation system with low-carbon output, low-carbon consumption, low-carbon resources, low-carbon policy and low-carbon environment [13]. Peng (2013) constructed an urban low-carbon traffic evaluation indicator system including lowcarbon technology, demand management and organization efficiency [14]. Zhao (2012) constructed the urban traffic low-carbon indicator system with carbon emission and motor vehicle pollutant emission as the main evaluation indicators [15]. Existing researches study on single index system or plan. This paper combines evaluation index system with management of low-carbon cities in order to provide reference benchmark and evaluation basis for cities throughout China to strive for green transport city, builds a low-carbon index system which is consistent with China's actual development in 
order to provide important basic support for scientific formulation of green transport city strategic planning and policies.

The remainder of the paper is organized as follows: Section 2 introduces about evaluation index system. Section 3 studies on empirical evaluation with typical case of Qingdao Transport; Section 4 is the conclusion and implication.

\section{Green Transport City Evaluation Index System}

\section{System framework and index selection}

The framework of evaluation index system includes:

(1) Vertical structure of index system: 1) overall score, which mainly reflects the degree of coordinated development of relations among evaluation indexes; 2) evaluation category, which sorts and integrates comprehensively a large amount of relevant information, and forms a sub-category index with clear significance; 3 ) evaluation content, which mainly reflects factors that shall be considered in each category, finds and seeks appropriate content to reflect characteristics of the development of green and low-carbon ports comprehensively and specifically; and 4) evaluation indexes, which mainly reflect specific content of factors.

(2) Horizontal structure of index system: this structure mainly includes index category hierarchy, index name and meaning, calculation method, index weight and evaluation standards, mainly based on four categories of indexes namely intensity indexes, system indexes, support indexes and characteristic indexes etc., each of which reflects a certain aspect of green transport city.

\section{Evaluation methods and standards}

(1) Evaluation methods. Intensity indexes are comprehensive quantitative indexes, set main index energy saving and emission reduction standards for competent port departments, calculate rate of reaching the standard and score; system indexes mainly include quantitative indexes; support indexes are mainly qualitative and score implementation of support work during construction of green and low-carbon ports; for characteristic indexes, ports could select autonomously according to their conditions, and shall better select quantitative ones.

(2) Evaluation basis and standards: primary data of evaluation indexes mainly comes from China Transport Statistical Yearbook and Collection of National Transport Statistical Data; statistical data of transportation of provinces or cities; major enterprise monitoring and typical survey data etc. Determine score standards of sub-indexes, measure average level, advanced level and backward level of indexes in terms of the country, provinces (municipalities, autonomous regions) and main cities respectively, benchmark international advanced level, and further determine evaluation scores of each category of cities. See table 1 for details of specific calculation.

\section{Evaluation Index System}

Evaluation system consists of four evaluation categories (intensity indexes, system indexes, support indexes and characteristic indexes), see Table 1. 
Table 1 Green Transport City Evaluation Index System

\begin{tabular}{|c|c|c|c|c|}
\hline \multicolumn{2}{|c|}{ Index category } & No. & Index name & \multirow{2}{*}{$\begin{array}{c}\begin{array}{c}\text { Weight } \\
\text { (Scores) }\end{array} \\
5\end{array}$} \\
\hline \multirow{10}{*}{$\begin{array}{l}\text { Intensity } \\
\text { Index } \\
(40 \\
\text { scores })\end{array}$} & \multirow{5}{*}{$\underset{\text { ty }}{\text { Energy Intensi- }}$} & & $\begin{array}{l}\text { Unit energy consumption of operational vehicles, unit: } \\
\text { kgce/hundred ton } \mathrm{km}\end{array}$ & \\
\hline & & 2 & $\begin{array}{l}\text { Unit energy consumption of operational ships, unit: kgce/thousand } \\
\text { ton km }\end{array}$ & 5 \\
\hline & & 3 & $\begin{array}{l}\text { Integrated port unit production energy consumption, unit: tce/ten } \\
\text { thousand ton throughput }\end{array}$ & 4 \\
\hline & & 4 & $\begin{array}{l}\text { Urban passenger transportation(City bus) unit passenger energy } \\
\text { consumption, unit: tce/ten thousand person-time }\end{array}$ & 3 \\
\hline & & 5 & $\begin{array}{l}\text { Urban passenger transportation(taxis) unit passenger energy con- } \\
\text { sumption, unit: tce/ten thousand person-time }\end{array}$ & 3 \\
\hline & \multirow{5}{*}{$\mathrm{CO}_{2}$ Intensity } & 6 & $\begin{array}{l}\text { Unit } \mathrm{CO}_{2} \text { emissions of operational vehicles, unit: } \mathrm{kg} \mathrm{CO}_{2} / \text { hundred } \\
\text { ton } \mathrm{km}\end{array}$ & 5 \\
\hline & & 7 & $\begin{array}{l}\text { Unit } \mathrm{CO}_{2} \text { emissions of operational ships, unit: } \mathrm{kg} \mathrm{CO}_{2} / \text { thousand } \\
\text { ton } \mathrm{km}\end{array}$ & 5 \\
\hline & & 8 & $\begin{array}{l}\text { Integrated port unit production } \mathrm{CO}_{2} \text { emissions, unit: } \mathrm{tCO}_{2} / \mathrm{ten} \\
\text { thousand ton throughput }\end{array}$ & 4 \\
\hline & & 9 & $\begin{array}{l}\text { Urban passenger transportation(City bus) unit passenger } \mathrm{CO}_{2} \\
\text { emissions, unit: } \mathrm{tCO}_{2} / \text { ten thousand person-time }\end{array}$ & 3 \\
\hline & & 10 & $\begin{array}{l}\text { Urban passenger transportation(taxis) unit passenger } \mathrm{CO}_{2} \text { emis- } \\
\text { sions, unit: } \mathrm{tCO}_{2} / \text { ten thousand person-time }\end{array}$ & 3 \\
\hline \multirow{10}{*}{$\begin{array}{c}\text { System } \\
\text { Index } \\
(\mathbf{3 0} \\
\text { scores })\end{array}$} & \multirow{3}{*}{ Infrastructure } & 11 & Construction of comprehensive transportation hub & 3 \\
\hline & & 12 & Proportion of special public lane in urban road & 3 \\
\hline & & 13 & Proportion of crawlway in urban road & 3 \\
\hline & \multirow{2}{*}{$\begin{array}{c}\text { Transport } \\
\text { Equipment }\end{array}$} & 14 & Proportion of energy-saving and environment-friendly vehicles & 3 \\
\hline & & 15 & Proportion of energy-saving and environment-friendly ships & 3 \\
\hline & \multirow{3}{*}{$\begin{array}{l}\text { Organization } \\
\text { Patter }\end{array}$} & 16 & $\begin{array}{l}\text { Proportion of water transportation and railway cargo transporta- } \\
\text { tion }\end{array}$ & 3 \\
\hline & & 17 & Sharing rate of buses in motor traveling & 3 \\
\hline & & 18 & Proportion of multimodal transport in transportation turnover & 3 \\
\hline & \multirow{2}{*}{ Intelligent Port } & 19 & Application of public traveling information service system & 3 \\
\hline & & 20 & Coverage rate of logistics public information platform & 3 \\
\hline \multirow{4}{*}{\multicolumn{2}{|c|}{$\begin{array}{l}\text { Supporting Index } \\
\quad(20 \text { scores })\end{array}$}} & 21 & Establishment and operation of organizations and institutions & 6 \\
\hline & & 22 & Energy saving and emission reduction evaluation system & 6 \\
\hline & & 23 & Technological innovation mechanism & 4 \\
\hline & & 24 & Energy saving and emission reduction promotion training & 4 \\
\hline \multicolumn{2}{|c|}{$\begin{array}{l}\text { Characteristic Index } \\
\quad(10 \text { scores })\end{array}$} & & $\begin{array}{l}\text { Self-defining items can be set according to city characteristics and } \\
\text { project innovation situation, and explain application reasons and } \\
\text { scores. Set } 2-5 \text { items, each of which shall not have above } 5 \text { scores } \\
\text { with total scores of } 10 \text {. }\end{array}$ & 10 \\
\hline
\end{tabular}

\section{Empirical analysis of green and low-carbon development level}

\section{Data}

Qingdao is an important economic central city and port city in the eastern coastal area of China, which had a GDP up to RMB 859.21 billion in 2014 with per capita GDP up to USD 11,000. Data of evaluation index system mainly comes from Collection of Transport Statistical Data, Qingdao Statistical Yearbook by Qingdao Statistical Bureau, and statistical data of Qingdao Port Group; and data of transport energy consumption statistical monitoring and typical surveys etc. Reference period of evaluation of current level is 2013, and the target year of planning pre-evaluation is 2020. According to actual development of Qingdao transport, a total of 4 categories of and 27evaluation indexes are set, among which, characteristic indexes mainly include density of clean energy supporting facilities 
(expressway density), ETC application promotion level (non-cash settlement rate, lane coverage rate) and logistics platform dispatching rate etc.

\section{Evaluation results \\ Overall evaluation results}

Qingdao has superior basic conditions to create a green transport city, and carries out a large amount of highly effective work, and obtains significant effects. It gets a total of 83 scores, and thus is a standard green transport city, and has generally a leading domestic level and good demo effects (Table 2).

By comparing main score deduction items of evaluation indexes, current gap and deficiencies of Qingdao can be found. These deficiencies mainly include: The urban traffic is seriously jammed, the urban public transportation priority level is not high; the resistance to update the natural gaspowered vessel is increased, and the proportion of energy-saving and environment-friendly trucks is relatively low; energy audit system, energy consumption and carbon emission statistical monitoring and other basic capacity building are in urgent need of being strengthened; green and low-carbon promotion shall be further promoted, etc. Qingdao shall accelerate construction of high-level, green transport city from these aspects.

\section{Sub-index evaluation results}

(1) In terms of strength indicator, the planning objective is completed comprehensively. The unit energy consumption of vehicles, ships and ports operated in 2013 were reduced by $9.2 \%, 8.9 \%$ and $5.4 \%$ respectively, meeting the target requirements of the "Twelfth-five Year" Planning period..

(2) In terms of system indicator, the work foundation is solid with a large improving space. On one hand, Qingdao Municipal Committee prepared the comprehensive traffic planning and special planning, with bus special road accounting for $1.1 \%$ of the urban road, crawlway accounting for $52.3 \%$, and hybrid power and natural gas passenger and cargo vehicles, urban buses and taxes respectively accounting for $3.3 \%, 45 \%$ and $84 \%$, in which the natural gas taxes account for the largest proportion, water transportation and railway cargo transportation account for $55.5 \%$, and Qingdao transportation public information service platform and Qingdao logistics public information platform have been constructed; on the other hand, in terms of the proportion o buses in the sharing of motor traveling, the proportion of multimodal transport in the comprehensive transportation turnover should be further increased, and substantial breakthrough is to be made in the energy-saving and environment-friendly ships.

(3) In terms of supporting indexes, system construction is carried forward orderly. Establish specialized energy-saving and emission reduction management department, and specialized management staffs are equipped; energy saving and emission reduction goals responsibility evaluation and appraisal system is built, and evaluation results are linked with energy saving and emission reduction rewards and punishment; build an energy-saving and emission reduction technological innovation mechanism to reward achievements such as invention and creation, technical transformation, technical innovation and innovative application etc. including energy saving and emission reduction. Accelerate publicity and training of energy saving and emission reduction, and train all levels of environmental protection leaders and management staffs at least once each year.

(4) In terms of characteristic indexes, there are distinct features and bright highlights. Besides the above general requirements, green and low-carbon development of Qingdao transport has still some unique and highlighted practice with certain influence and comparative advantages at home and abroad, mainly including: The density of clean energy supporting facilities (expressway density) is up to above $1 / 100 \mathrm{~km}$, the non-cash settlement rate and lane coverage rate of ETC application promotion in Qingdao re respectively up to $8 \%$ and $99 \%$, and the logistics platform dispatching rate is up to $60 \%$. 
Table 2 Evaluation results of green and low-carbon development status and planning of Qingdao

\begin{tabular}{|c|c|c|c|c|c|c|c|}
\hline \multicolumn{2}{|c|}{ Index category } & \multirow{2}{*}{\begin{tabular}{|c|} 
No. \\
1 \\
\end{tabular}} & Index name & \multirow{2}{*}{$\begin{array}{c}\begin{array}{c}\text { Weight } \\
\text { (Scores) }\end{array} \\
5 \\
\end{array}$} & \multirow{2}{*}{\begin{tabular}{|c|}
$\begin{array}{c}2013 \\
\text { Current ) }\end{array}$ \\
5 \\
\end{tabular}} & \multirow{2}{*}{\begin{tabular}{|c}
$\begin{array}{c}2018 \\
\text { (Target) }\end{array}$ \\
5
\end{tabular}} & \multirow{2}{*}{\begin{tabular}{|c|c|}
$\begin{array}{c}2020 \\
\text { (Target }\end{array}$ \\
5
\end{tabular}} \\
\hline \multirow{10}{*}{$\begin{array}{c}\text { Intensity } \\
\text { Index } \\
(40 \\
\text { scores })\end{array}$} & \multirow{5}{*}{$\begin{array}{l}\text { Energy Inten- } \\
\text { sity }\end{array}$} & & $\begin{array}{l}\text { Unit energy consumption of operational } \\
\text { vehicles }\end{array}$ & & & & \\
\hline & & & $\begin{array}{l}\text { Unit energy consumption of operational } \\
\text { ships }\end{array}$ & 5 & 5 & 5 & 5 \\
\hline & & & $\begin{array}{l}\begin{array}{l}\text { Integrated port unit production energy } \\
\text { consumption }\end{array} \\
\end{array}$ & 4 & 4 & 4 & 4 \\
\hline & & & $\begin{array}{l}\text { Urban passenger transportation(City bus) } \\
\text { unit passenger energy consumption }\end{array}$ & 3 & 3 & 3 & 3 \\
\hline & & & $\begin{array}{l}\text { Urban passenger transportation(taxis) unit } \\
\text { passenger energy consumption }\end{array}$ & 3 & 3 & 3 & 3 \\
\hline & \multirow{5}{*}{$\begin{array}{l}\mathrm{CO}_{2} \text { Intensi- } \\
\text { ty }\end{array}$} & 6 & Unit $\mathrm{CO}_{2}$ emissions of operational vehicles & 5 & 5 & 5 & 5 \\
\hline & & 7 & Unit $\mathrm{CO}_{2}$ emissions of operational ships & 5 & 5 & 5 & 5 \\
\hline & & & \begin{tabular}{|llll}
$\begin{array}{l}\text { Integrated port } \\
\text { emissions }\end{array}$ & unit production $\mathrm{CO}_{2}$ \\
\end{tabular} & 4 & 4 & 4 & 4 \\
\hline & & & $\begin{array}{l}\text { Urban passenger transportation(City bus) } \\
\text { unit passenger } \mathrm{CO}_{2} \text { emissions }\end{array}$ & 3 & 3 & 3 & 3 \\
\hline & & 10 & $\begin{array}{l}\text { Urban passenger transportation(taxis) unit } \\
\text { passenger } \mathrm{CO}_{2} \text { emissions }\end{array}$ & 3 & 3 & 3 & 3 \\
\hline \multirow{10}{*}{$\begin{array}{c}\text { System } \\
\text { Index } \\
(30 \\
\text { scores })\end{array}$} & \multirow{3}{*}{ Infrastructure } & 11 & $\begin{array}{l}\text { Construction of comprehensive transporta- } \\
\text { tion hub }\end{array}$ & 3 & 3 & 3 & 3 \\
\hline & & 12 & $\begin{array}{l}\text { Proportion of special public lane in urban } \\
\text { road }\end{array}$ & 3 & 2 & 3 & 3 \\
\hline & & 13 & Proportion of crawlway in urban road & 3 & 2 & 2 & 3 \\
\hline & \multirow{2}{*}{$\begin{array}{l}\text { Transport } \\
\text { Equipment }\end{array}$} & 14 & $\begin{array}{l}\text { Proportion of energy-saving and environ- } \\
\text { ment-friendly vehicles }\end{array}$ & 3 & 2 & 2 & 3 \\
\hline & & 15 & $\begin{array}{l}\text { Proportion of energy-saving and environ- } \\
\text { ment-friendly ships }\end{array}$ & 3 & 0 & 3 & 3 \\
\hline & \multirow{3}{*}{$\begin{array}{l}\text { Organization } \\
\text { Patter }\end{array}$} & 16 & $\begin{array}{l}\text { Proportion of water transportation and } \\
\text { railway cargo transportation }\end{array}$ & 3 & 3 & 3 & 3 \\
\hline & & 17 & Sharing rate of buses in motor traveling & 3 & 0 & 3 & 3 \\
\hline & & 18 & \begin{tabular}{|l|l|}
$\begin{array}{l}\text { Proportion of multimodal transport in } \\
\text { transportation turnover }\end{array}$ \\
\end{tabular} & 3 & 0 & 0 & 1 \\
\hline & \multirow{2}{*}{$\begin{array}{l}\text { Intelligent } \\
\text { Port }\end{array}$} & 19 & $\begin{array}{l}\text { Application of public traveling information } \\
\text { service system }\end{array}$ & 3 & 3 & 3 & 3 \\
\hline & & 20 & $\begin{array}{l}\text { Coverage rate of logistics public informa- } \\
\text { tion platform }\end{array}$ & 3 & 3 & 3 & 3 \\
\hline \multirow{4}{*}{\multicolumn{2}{|c|}{$\begin{array}{l}\text { Supporting Index } \\
\text { (20 scores) }\end{array}$}} & 21 & $\begin{array}{l}\text { Establishment and operation of organiza- } \\
\text { tions and institutions }\end{array}$ & 6 & 6 & 6 & 6 \\
\hline & & 22 & $\begin{array}{l}\text { Energy saving and emission reduction } \\
\text { evaluation system }\end{array}$ & 6 & 3 & 6 & 6 \\
\hline & & 23 & Technological innovation mechanism & 4 & 2 & 2 & 4 \\
\hline & & & $\begin{array}{l}\text { Energy saving and emission reduction } \\
\text { promotion training }\end{array}$ & 4 & 4 & 4 & 4 \\
\hline \multirow{3}{*}{\multicolumn{2}{|c|}{$\begin{array}{l}\text { Characteristic Index } \\
\text { (10 scores) }\end{array}$}} & 25 & $\begin{array}{l}\text { Density of clean energy supporting facili- } \\
\text { ties (expressway density) }\end{array}$ & 4 & 4 & 4 & 4 \\
\hline & & 26 & ETC application promotion level & 3 & 3 & 3 & 3 \\
\hline & & 27 & Logistics platform dispatching rate & 3 & 3 & 3 & 3 \\
\hline & total & & & 100 & 83 & 92.5 & 98 \\
\hline
\end{tabular}




\section{Conclusions}

This paper discusses about a green and low-carbon port evaluation index system, and conducts empirical research with case study of Qingdao, and reaches the following conclusions:

(1)Based on four categories of indexes such as intensity indexes etc., this paper discusses about and builds a green and low-carbon city evaluation index system. Where: as comprehensive performance index, intensity index are in line with stage characteristics of the development of Chinese ports, and play a strongly strategic guiding role; system indexes and support indexes are strongly systematical and unified, comprehensively systematical, simple, practical and convenient to operate; meanwhile, characteristic indexes can fully reflect development status, highlight green transport city features, help stimulate exploration and innovation, and thus show good expandability.

(2)Empirical research indicates that green transport city evaluation index system proposed in this paper has good practicability. Empirical evaluation of Qingdao shows that evaluation index system proposed in this paper has good practicability, as this system applies not only for objective evaluation of development status of green transport city, summarizing effects, recognizing advantages, carrying forward experience, analyzing problems, finding the gap and making up for the deficiencies, but also for establishment of green transport city strategic development planning goal system, realizing scientific anticipation of planning perspective, and thus taking targeted measures to "enhance the strong and make up for the weak, enhance advantages and avoid disadvantages".

\section{Acknowledgements}

The authors gratefully acknowledge the financial support from China Postdoctoral Science Foundation Grant No. 2015M570999, Ministry of Transport Energy-saving and Emission-reduction Project Grant No. 2014-JNJP-003-032, China Climate Technology Needs Assessment Project Grant No. TF012536.

\section{References}

[1] Y.M. Wei, H. Liao, et al., China Energy Report 2010: Energy Efficiency Research. Science Press, Beijing (2010).

[2] Ministry of Transport. Green low-carbon transport development annual report 2011, People's Communications Press, Beijing (2013).

[3] B. Ouyang, Z.K. Li, Z.H. Feng, The Current Situation, Problems and Prospect of Research on Low-carbon Transport Planning. China Business and Market 19(2014): 13-20.

[4] China low-carbon development strategy research group. China Low Carbon Transport Development Strategy. China Academic of Transportation Sciences 2015.

[5] J.Y. Long, Evaluation Model and Optimization Method of Urban Passenger Transport System Based on Carbon Emission Target, Huazhong University of Science \& Technology, Wuhan (2011)

[6] K.Y.Wu, C.H.He, G.X.Wang, et al., Measurement and Decomposition Analysis on Carbon Emissions of Transportation Industry in Shanghai. Economic Geography, 32: 45-51(2012)

[7] B.Y. Gao, W.D. Liu. Emissions reduction potential analysis of road transport. Geographical Research. 32, 767-775, (2013)

[8] B. Ouyang, Y.J. Zhang, J. Guo, The Comprehensive Evaluation Indicators for Low-carbon Transport and Applications. Journal of Beijing Institute of Technology (SOCIAL SCIENCE EDITION) 3(2014): In press

[9] P. Peng. Analysis on Comprehensive Evaluation and Development Approaches of Urban Lowcarbon Traffic. Beijing Jiaotong University (2013).

[10] OECD, Organization for Economic Development and Co-operation (OECD). OECD Key Environmental Indicators 35 (2008).

[11] A.S. Dagoumas, T. S. Barker, Pathways to a low-carbon economy for the UK with the macroeconometric E3MG model. Energy Policy 38(2010):3067-3077. 
[12] S. Koji, T.Yoshitaka, G. Kei, et al. Developing a Long-term Local Society Design Methodology towards a Low-carbon Economy: An Application to Shiga Prefecture in Japan [J]. Energy Policy, 2007, 35(9):4688-4703.

[13] J. F. Fu, G. Y. Zhuang, Q. X. Gao, Conceptual Identification and Evaluation Index System for Low Carbon Economy. China Population Resources and Environment 20(2010): 23-43.

[14] P. Peng, Analysis on Comprehensive Evaluation and Development Approaches of Urban Lowcarbon Traffic. Beijing Jiaotong University, Beijing(2013).

[15] H. Zhao, H. Jiang, N. Wu, A Simulation- based Evaluation Method for Low-carbon Transportation Strategy. Journal of Transportation Information and Safety (30) 2012: 34-38. 